\title{
The therapeutic effects of manipulation technique on sacroiliac joint dysfunction in young women
}

\author{
Ashraf Vaseghnia ${ }^{1}$ \\ Azadeh Shadmehr ${ }^{2}$ \\ Behrouz Attarbashi Moghadam ${ }^{3}$ \\ Gholamreza Olyaei ${ }^{4}$ \\ Mohammad Reza Hadian 4 \\ Zahra Khazaeipour ${ }^{5}$ \\ 1 PhD candidate of Physical Therapy Department, \\ School of Rehabilitation, Tehran University \\ of Medical Sciences, Tehran, Iran \\ 2 Physical Therapy Department, School of Rehabilita- \\ tion, Tehran University of Medical \\ Sciences, Tehran, Iran \\ 3 Physical Therapy Department, School of Rehabilita- \\ tion, Tehran University \\ of Medical Sciences, Tehran, Iran \\ 4 Physical Therapy Department, School of Rehabilita- \\ tion, Tehran University of Medical \\ Sciences, Tehran, Iran \\ 5 Brain and Spinal Injury Repair Research Center, \\ Neuroscience Institute, Tehran University of \\ Medical Sciences, Tehran, Iran
}

Corresponding author:

Azadeh Shadmehr

Physical Therapy Department,

School of Rehabilitation,

Tehran University of Medical Sciences

School of Rehabilitation, Piche Shemiran, Enghelab

Street, Tehran, Iran

Tel.: 9821-77528468

Fax: 9821-77528468

E-mail: shadmehr@tums.ac.ir

\section{Summary}

Introduction: The aims of this research was to measure the effects of manipulation by remarking the type of dysfunction and the orientation of the correcting maneuver in patients with iliosacral joint dysfunctions.

Methods: Sixty women with ant innominate or post innominate dysfunctions were gathered for the research and divided into two groups, treatment group received a session of manipulation and the control group randomly $(\mathrm{N}=30)$. The range of flexion and extension of the lumbar, internal and external rotations of the hip, VAS, active SLR and pressure pain threshold were evaluated before, immediately and 24 hours after manipulation.

Results: As per the results of this study, in treatment group, manipulation had helped to relieve the level of pain and decreased the mean score of ASLR and its effects remained up to 24 hours $(p<0.05)$ and also increased immediately the ROM of the hip internal and external rotations and the lumbar flexion and extension $(p<0.05)$ but in control group we didn't see any significant difference ( $p>0.05)$. We didn't see any significant difference at PPT before, immediately after and 24 hours after manipulation in patients in both groups $(p>0.05)$.

Conclusion: Applying manipulation regarding the kind of dysfunction may be reducing patient's symptoms.

Level of evidence: Ib.

KEY WORDS: ant innominate rot, manipulation, sacroiliac dysfunctions, post innominate rot.

\section{Introduction}

Low back pain (LBP) is a common, costly, and challenging problem to manage whose level of prevalence is $84 \%$ in the general adult population. It has also reported that a large group (up to $30 \%$ ) of patients with low back pain includes sacroiliac joint (SIJ) disorder ${ }^{1}$. The high prevalence of functional impairment of this joint indicates that it is valued to investigate it as a subject of research.

Vleeming et al., in 2012, emphasized Donatelli's studies that understanding and learning the structure and functional disorders of the sacroiliac joint is essential for learning the function of the spine. He stated that the biomechanical role of SIJ in the transferring of the weight to the lower limb is very important and any disruptions in the alignment of the SIJ cause pain and disorders in the joint ${ }^{2}$. Therefore, the treatment based on joint biomechanical correction can be considered as an appropriate solution for sacroiliac disorders.

There are some evidences about failure of traditional treatments in functional impairments of sacroiliac joint ${ }^{3}$.

Manipulation is defined as a passive and thrust movement that causes the joints to return to the cor- 
rect position. This technique is performed at high speed and low amplitude at the end of the range of motion, which is applied to the synovial joint in a short time ${ }^{4}$.

It's believed that manipulation has some therapeutic effects, including stretching the soft tissue around the joint, improve the range of motion and correct the malposition of the joints. Manipulation also releases synovial entrapment and soft tissue adhesions around the joints to restore normal movements and improve their ROM ${ }^{5}$.

According to researchers such as Carlesso et al., Fly$\mathrm{nn}$ et al. and Cook et al., manipulation has a significant effect on joint asymmetry, hypo mobility, and the treatment of abnormal soft tissues of the musculoskeletal system (tissue texture) ${ }^{6,7}$.

In previous studies, manipulation was performed on patients with non-specific low back pain or sacroiliac dysfunctions generally and unfortunately most of them have used a common therapeutic technique for various types of functional SIJ disorders ${ }^{6,7}$. Therefore, the purpose of our research was the short term evaluation of the therapeutic effects of manipulation by deliberating the type of dysfunction and direction of the corrective maneuver in patients with iliosacral joint dysfunction (ant innominate rotation or post innominate rotation). In fact, the main advantage of this study is to select a specific group of patients with SIJ disorders and the implication of a specific technique for each dysfunction.

\section{Materials and methods}

This study was single double randomized quasi-experimental and was approved by the Ethics Committee of Tehran University of Medical Sciences (IR.TUMS.VCR.REC.1395.211) and Iranian Registry Clinical Trial (IRCT20171126037633N1). The study meets the ethical standards of the journal ${ }^{8}$.

Patients were stricken from unilateral SIJ pain for more than a year with an initial diagnosis of lumbosacral disorders by orthopedic specialists and then patients referred to the physiotherapy clinic. They take part in this study after fulfilling and signing a consent form and a questionnaire to exclude low back pathologies and then they underwent physical examination and eight specific sacroiliac joint tests ${ }^{5}$. Sixty women with ant innominate or post innominate dysfunctions were gathered in the study (ranging from 19 to 39 years in age with a mean age of 28.10 years).

Patients were randomly divided into two groups: treatment group $(\mathrm{N}=30)$ received manipulation and the control group $(\mathrm{N}=30)$.

\section{Sample size}

This study is based on the results of pilot study and considering $\alpha=0.05$ and $\beta=20 \%$, the sample size was determined using the following formula:

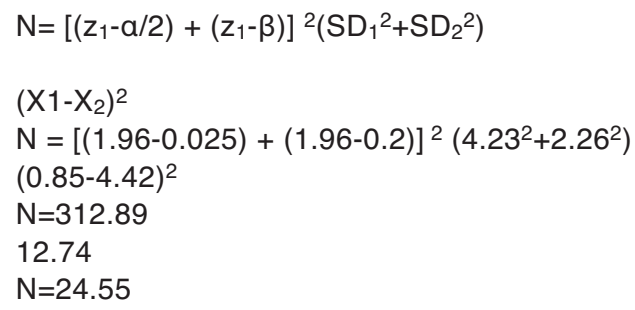

Table I. Results of pilot study.

\begin{tabular}{llll}
\hline & N & Mean & SD \\
\hline VASAMET & 7 & 4.4286 & 4.23703 \\
VASAM & 7 & .8571 & 2.26779 \\
Valid N (listwise) & 7 & & \\
\hline
\end{tabular}

With regard to the probability that a number of patients will be excluded from the study, the number of patients in each group will be 30 .

\section{Inclusion and exclusion criteria}

Participant with ant innominate or post innominate dysfunctions and whose level of current pain was at least three as per the Visual Analogue Scale (VAS) were contained in the study (the map pain of the SIJ dysfunctions is between PSIS and gluteal fold that rather on the joint ${ }^{9}$ ).

Patients with any pathology in the lower extremities and spine, central and peripheral nervous system and lower extremities were excluded.

The following tests were operated on the patients for their entry in the study: measuring the distance between the umbilicus and the ASIS, iliac crests height, levelness of the PSISs, levelness of the ASISs, Standing Flex test, Gillet test, Long-Sitting test and Provocation tests.

Measuring the distance between the umbilicus and the ASIS was applied to deprive the practitioners with in flare and out flare of ilium dysfunction.

Because of the high reliability and validity of the Provocation and Long-Sitting test the results of these two tests for detecting ant innominate or post innominate dysfunctions had to be positive ${ }^{10}$ and the results of three of the five tests containing iliac crest height, levelness of the PSISs, and levelness of the ASISs, Standing Flex Test, and Gillet Test for the diagnosis of ant innominate or post innominate dysfunction should be positive, too ${ }^{11}$.

\section{Protocol}

All outcome measures were collect by the same examiner (Examiner 1), who was blinded to treatment group division.

The outcome evaluation contained: 1) the range of the flexion and the extension of the lumbar spine; 2) the range of the internal and the external rotations of the hip; 3) level of pain according to the VAS; 4) Ac- 
tive straight leg raising (ASLR); 5) pressure pain threshold (PPT) at five points (right PSIS, right SIJ, left PSIS, left SIJ, and the right deltoid).

\section{Flexion and extension of lumbar spine}

We were using the modified Schober test for measuring of the lumbar range of motion. Modified Schober test has high validity and inter- and intrarater reliabilities ${ }^{12}$. We stood behind the patient that was made to stand and put our thumbs on the PSISs. We wanted to her that shifted to backwards and forwards and in order to prevent of pelvic motion when the PSISs began to move we asked her to stop. Then with a flexible ruler, we measured the difference in the distance between the two skins points $(5 \mathrm{~cm}$ below and $10 \mathrm{~cm}$ above the second sacral vertebra or the line between the PSISs) during move back and forth ${ }^{13}$.

An increasing distance in move forth and a decreasing distance in move back were indicated the increasing of flexion and extension. These evaluations were accomplished three times and their average was applied for the analysis.

\section{Hip internal and external rotations}

We had measured the internal and the external rotations of the hip when the patient was sitting the edge of the bed, with $90^{\circ}$ flexion of the hips and knees, hip was placed between abduction and adduction in the neutral position. We put the axis of the goniometer at the center of the patella and the stationary arm was placed vertically and the motion arm was aligned with crest of tibia and to increase the accuracy of the goniometer and to better determine the perpendicular position, a plumb line mounted along the fixed goniometer arm was used.

The patient moved the hip outside and inside actively, and the range of the motion of the hip was measured. During the evaluation, the opposite knee was flexed less than $90^{\circ}$ to prevent helping the movement and we prevented compensatory motions such as hip adduction or abduction, hip raising from the table and lateral bending of the trunk during the evaluation ${ }^{14}$. These evaluations were accomplished three times and their average was applied for the analysis.

\section{Visual analogue scale (VAS)}

The VAS was applied to measuring of the level of the present pain. It was $10 \mathrm{~cm}(100 \mathrm{~mm})$ line that describes no pain on the left end $(0)$ and describes the worst pain or very severe pain (10) on the right end indicating. We wanted the patient to trace a vertical sign on each line to show her level of existing pain ${ }^{15}$.

\section{Active straight leg raising (ASLR)}

To perform ASLR test, a patient was made to lie on her back and raised her striated leg $20 \mathrm{~cm}$ off the table with any lateral bending or rotating of the lower extremity.

Based on the patient's ability to doing the movement the test was scored: the score of 0 (zero) was given when the patient performed the test without any pain or heaviness and tremor. The score of 1 (one) was given when the patient stated that her ability to lifting the leg was low, but we didn't see any symptoms of movement disorders such as tremor or rotation of the lower extremity. The score of 2 (two) was given when the patient reported that her ability to lifting the leg was low and we also saw symptoms of movement disorders such as tremor or rotation of the lower extremity, and if the patient was unable to doing the test, it was scored as 3 (three) $^{16}$.

\section{Pressure pain threshold (PPT)}

We used of a digital algometer (Model J-Tech) to measuring of the PPT that it is a valid and reliable device for measuring $\mathrm{PPT}^{17}$. We put vertically the algometer on five-points: 1) right SIJ; 2) right PSIS; 3) left SIJ; 4) left PSIS; 5) the bulk of the right deltoid. The PSISs are touched at $4 \mathrm{~cm}$ outside the center line at the level of S2 in inferior and depth of the skin dimples and SIJs are touched $2 \mathrm{~cm}$ lateral and inferior of the PSISs ${ }^{18}$. We pressured algometer at a constant speed until the patient begun feeling pain at that point and recorded the number displayed in the algometer at that time.

Subjects were randomly devoted by a third person who unknown to Examiner 1 and 2, using a random number to treatment (manipulation) or control (sham position) group.

Examiner 2 had performed the intervention to the treatment or control group.

The control group placed in sham position by side lying on a treatment table for 2 minutes. After before and after measurements and at the end of study, they were introduced to the physiotherapy clinic and received routine treatment.

\section{Intervention}

Manipulation. In this study, the patients received one session of manipulation. It should be mentioned that the technique was carried out by a physiotherapist with a history of 10 years of manual therapy, and confirmed and inspected by the study's supervisor.

To correct right anterior innominate rotation, the patient was made to lie on side so that the affected side was upward. We stood in front of the patient; first we put her shoulders, pelvis and lower limbs in neutral position and place the right hand on the ASIS and the left hand on the ischium tuberosity and with a rotational movement of the hands, rotated ilium to the posterior. At the end of the range, we replace the position of hands and place the left forearm on the ischium tuberosity and place the right hand on the upper patient's shoulder and move it toward the bed at the end of the range with patient's exhalation, we did a trust movement (Fig. 1).

To correct left anterior innominate rotation, the patient position was like right anterior innominate rotation and we replace the position of our hands ${ }^{5}$.

To correct right posterior innominate rotation, the patient was made to lie on side so that the affected side was upward. We stood in front of the patient; first we 
put her shoulders, pelvis and lower limbs in neutral position then placed our right finger on the lumbosacral joint and extended the lower limbs with the left hand until to feeling the first movement in the lumbosacral joint then bend the upper knee and place the upper foot behind the lower leg. We put the right forearms on the trunk and push the trunk to the bed to reach the end of the range and at the same time, we put our right pisiform bone on PSIS and rotate the pelvis to the front. At the end of the range, replace the pisiform with right forearm on PSIS and with a forearm, with a patient exhalation, we did a trust movement (Fig. 2).

To correct left posterior innominate rotation, the patient position was like right posterior innominate rotation and we replace the position of our hands ${ }^{5}$.

It should be mentioned that while doing the technique, the patient's breathing should be relaxed 5 .

We re-checked the patient immediately after the technique to assess the functional disorders of sacroiliac joint and if the she had functional disorders of SIJ, we performed the technique on the patient again. After the re-check if the results of tests were positive again, the patient divested from the study.

The outcome measurements were measured before, immediately and 24 hours after manipulation.

The physical conditions such as chamber lighting, temperature and time and place were the same in all the cases. Also we asked each patient the time of her monthly periods and didn't perform the techniques on her in those days.

The plan and the aims of the study were fully described to all the participants and the tests begun only after they agreed and signed the consent form pur- posely. At every level, the tests were to be suspended if there weren't co-participants. All the patients were confident that their data would remain strictly private and we also made the participants informed of the possible side effects of the intervention, and in case of any problem, we would take accountability and offset them as much as feasible.

We used SPSS software version 21 to analyze the data and the one-sample Kolmogorov-Smirnov test was apply to measure the normal distribution of the data and it showed that the distribution of all the variables were normal $(p>0.05)$. Repeated measurement tests illustrate a statistically significant difference in the variables before, immediately and 24 hours after the manipulation in two groups. Significance level was set at $p<0.05$.

\section{Results}

After applying one-sample Kolmogorov-Smirnov test we saw that the distribution of all the variables in two groups were normal $(p>0.05)$. Table II presents the data of the anthropometric characteristics of the 60 participants that there were no statistically significant differences in anthropometric data between two groups.

The results of the repeated measurement tests in 2 groups are shown in Table III. This table shows that some variables before, immediately and 24 hours after the intervention had significant difference $(p<0.05)$ with corresponding $95 \%$ confidence intervals $(95 \% \mathrm{Cl})$.

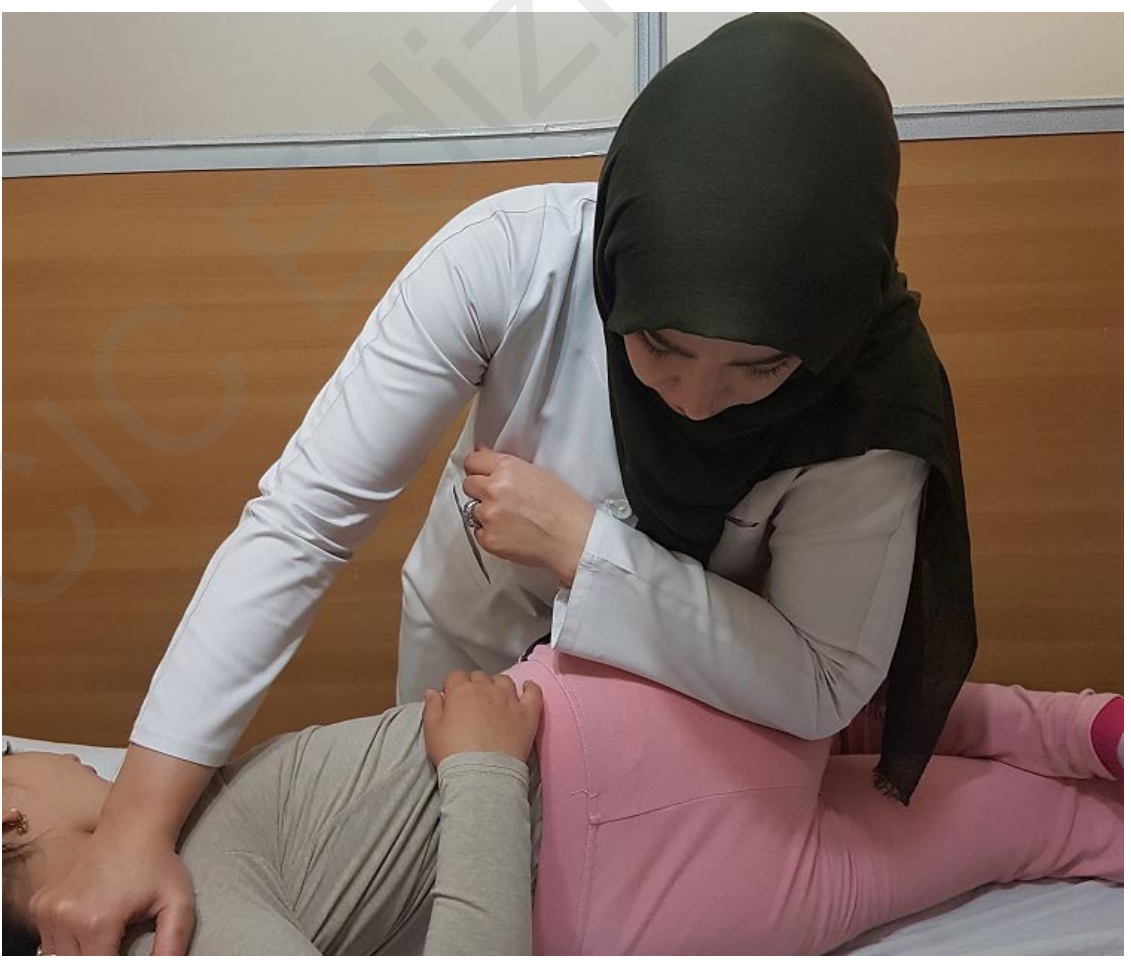

Figure 1. Manipulation technique for correction of right anterior innominate rotation. 


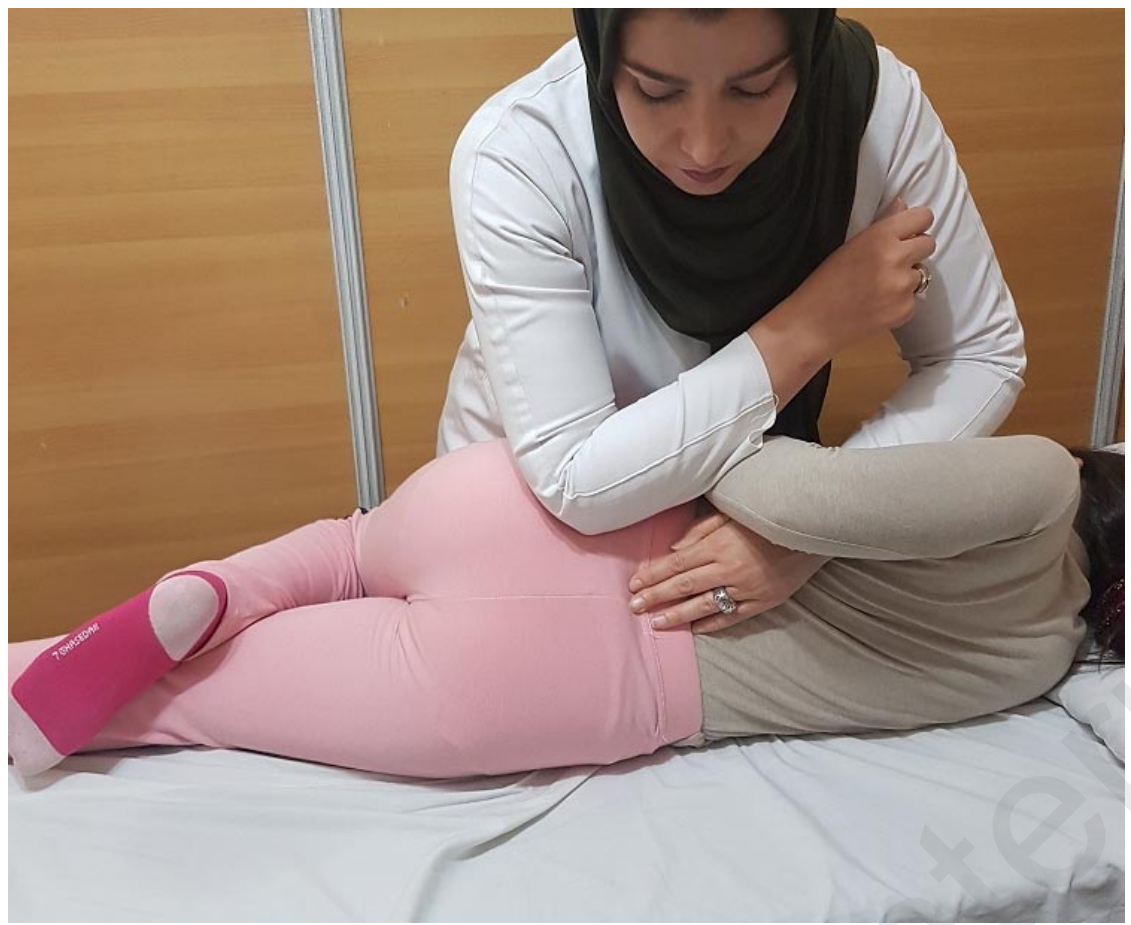

Figure 2. Manipulation technique for correction of left anterior innominate rotation.

\section{Lumbar flexion and lumbar extension}

The average distance between the two skin points during flexion with the modified Schober test in treatment group, at pretest, after the test and 24 hours after the test were shown that the range of lumbar flexion of the patient before and immediately after the intervention went on growing and 24 hours after the intervention went on decreasing but the amount of reduction is not such that the lumbar flexion is less than that before intervention and there hasn't seen any significant deference in the control group at pretest, immediately and 24 hours after the test (Tab. III).

The average distance between the two skin points during extension with the modified Schober test at pretest, after the test and 24 hours after the test were shown that the range of range of lumbar extension for the patient before and immediately after the intervention went on growing and 24 hours after the intervention went on decreasing but the amount of reduction is not such that the lumbar extension is less than that before intervention in treatment group and there has- n't seen any significant deference in the control group at pretest, immediately and 24 hours after the test (Tab. III).

The mean change of the range of lumbar flexion and extension before, immediately after and 24 hours after the manipulation than sham position showed that there was significant changes $(p<0.05)$, and the maximum increase occurred immediately after intervention.

It's notable that decreasing distance between the two skin points during extension indicates the increasing the range of extension.

\section{Hip internal and external rotations}

The average range of hip internal rotations and external rotation of the patients have shown that the range of hip internal rotation and external rotation of the subjects in treatment group at before and immediately after the manipulation went on growing and 24 hours after the manipulation went on decreasing and there hasn't seen any significant deference in the

Table II. Anthropometric characteristic of the participants $(\mathrm{N}=60)$.

\begin{tabular}{llll}
\hline Variables & Mean & SD & Range \\
\hline Age (year) & 28.10 & 5.30 & $19-39$ \\
Weight $(\mathrm{kg})$ & 63.93 & 12.92 & $43.0-90.0$ \\
Height $(\mathrm{m})$ & 1.63 & .05 & $1.53-1.76$ \\
BMl $\left(\mathrm{kg} / \mathrm{m}^{2}\right)$ & 23.57 & 3.54 & $17.30-29.41$ \\
\hline
\end{tabular}


Table III. The mean and SD of the results before, immediately and $24 \mathrm{~h}$ after hours in two groups $(\mathrm{N}=30)$.

\begin{tabular}{|c|c|c|c|c|c|c|}
\hline variable & Group & $\begin{array}{l}\text { Before } \\
\text { mean } \pm(S D)\end{array}$ & $\begin{array}{l}\text { Immediately } \\
\text { mean } \pm(S D)\end{array}$ & $\begin{array}{l}24 \mathrm{~h} \text { after } \\
\text { mean } \pm(S D)\end{array}$ & $\begin{array}{l}\text { p-value } \\
\text { within- } \\
\text { groups }\end{array}$ & $\begin{array}{l}p \text {-value } \\
\text { between- } \\
\text { groups }\end{array}$ \\
\hline Lumbar flex (cm) & $\begin{array}{l}\text { Manipulation } \\
\text { Control }\end{array}$ & $\begin{array}{l}19.63 \pm(0.91) \\
19.73 \pm(0.83)\end{array}$ & $\begin{array}{l}21.60 \pm(0.86) \\
20.03 \pm(0.92)\end{array}$ & $\begin{array}{l}20.26 \pm(0.93) \\
19.97 \pm(0.89)\end{array}$ & $\begin{array}{l}0.000 \\
0.34\end{array}$ & 0.04 \\
\hline Lumbar ext (cm) & $\begin{array}{l}\text { Manipulation } \\
\text { Control }\end{array}$ & $\begin{array}{l}13.40 \pm(0.63) \\
13.61 \pm(0.71)\end{array}$ & $\begin{array}{l}11.80 \pm(0.68) \\
13.73 \pm(0.73)\end{array}$ & $\begin{array}{l}12.95 \pm(0.72) \\
13.53 \pm(0.80)\end{array}$ & $\begin{array}{l}0.000 \\
0.42\end{array}$ & 0.01 \\
\hline ASLR & $\begin{array}{l}\text { Manipulation } \\
\text { Control }\end{array}$ & $\begin{array}{l}2.63 \pm(0.49) \\
2.35 \pm(0.32)\end{array}$ & $\begin{array}{l}0.90 \pm(0.54) \\
2.24 \pm(0.48)\end{array}$ & $\begin{array}{l}0.33 \pm(0.47) \\
2.42 \pm(0.39)\end{array}$ & $\begin{array}{l}0.000 \\
0.15\end{array}$ & 0.02 \\
\hline Hip int rot (degree) & $\begin{array}{l}\text { Manipulation } \\
\text { Control }\end{array}$ & $\begin{array}{l}26.30 \pm(5.97) \\
25.4 \pm(4.39)\end{array}$ & $\begin{array}{l}33.53 \pm(5.96) \\
26.0 \pm(6.12)\end{array}$ & $\begin{array}{l}30.20 \pm(6.14) \\
25.5 \pm(5.76)\end{array}$ & $\begin{array}{l}0.000 \\
0.31\end{array}$ & 0.00 \\
\hline Hip ext rot (degree) & $\begin{array}{l}\text { Manipulation } \\
\text { Control }\end{array}$ & $\begin{array}{l}23.93 \pm(5.81) \\
23.5 \pm(4.37)\end{array}$ & $\begin{array}{l}30.63 \pm(5.95) \\
24.12 \pm(5.11)\end{array}$ & $\begin{array}{l}27.26 \pm(6.32) \\
23.92 \pm(4.93)\end{array}$ & $\begin{array}{l}0.000 \\
0.47\end{array}$ & 0.01 \\
\hline VAS & $\begin{array}{l}\text { Manipulation } \\
\text { Control }\end{array}$ & $\begin{array}{l}5.70 \pm(0.91) \\
5.97 \pm(1.12)\end{array}$ & $\begin{array}{l}2.20 \pm(1.42) \\
5.63 \pm(0.98)\end{array}$ & $\begin{array}{l}1.23 \pm(1.00) \\
5.37 \pm(1.03)\end{array}$ & $\begin{array}{l}0.000 \\
0.21\end{array}$ & 0.03 \\
\hline $\begin{array}{l}\text { PPT right PSIS } \\
\left(\mathrm{kg} / \mathrm{cm}^{2}\right)\end{array}$ & $\begin{array}{l}\text { Manipulation } \\
\text { Control }\end{array}$ & $\begin{array}{l}3.22 \pm(0.65) \\
3.45 \pm(0.54)\end{array}$ & $\begin{array}{l}3.27 \pm(0.70) \\
4.01 \pm(0.46)\end{array}$ & $\begin{array}{l}3.29 \pm(0.67) \\
3.89 \pm(0.39)\end{array}$ & $\begin{array}{l}0.35 \\
0.67\end{array}$ & 0.27 \\
\hline $\begin{array}{l}\text { PPT right SIJ } \\
\left(\mathrm{kg} / \mathrm{cm}^{2}\right)\end{array}$ & $\begin{array}{l}\text { Manipulation } \\
\text { Control }\end{array}$ & $\begin{array}{l}3.28 \pm(0.83) \\
4.09 \pm(0.79)\end{array}$ & $\begin{array}{l}3.52 \pm(1.39) \\
3.89 \pm(0.91)\end{array}$ & $\begin{array}{l}3.36 \pm(0.81) \\
3.92 \pm(0.75)\end{array}$ & $\begin{array}{l}0.15 \\
0.23\end{array}$ & 0.36 \\
\hline $\begin{array}{l}\text { PPT left PSIS } \\
\left(\mathrm{kg} / \mathrm{cm}^{2}\right)\end{array}$ & $\begin{array}{l}\text { Manipulation } \\
\text { Control }\end{array}$ & $\begin{array}{l}3.27 \pm(0.71) \\
3.36 \pm(0.86)\end{array}$ & $\begin{array}{l}3.34 \pm(0.71) \\
3.61 \pm(0.69)\end{array}$ & $\begin{array}{l}3.34 \pm(0.74) \\
3.58 \pm(0.77)\end{array}$ & $\begin{array}{l}0.26 \\
0.37\end{array}$ & 0.19 \\
\hline $\begin{array}{l}\text { PPT left SIJ } \\
\left(\mathrm{kg} / \mathrm{cm}^{2}\right)\end{array}$ & $\begin{array}{l}\text { Manipulation } \\
\text { Control }\end{array}$ & $\begin{array}{l}3.53 \pm(0.84) \\
3.85 \pm(0.62)\end{array}$ & $\begin{array}{l}3.51 \pm(0.89) \\
3.92 \pm(0.76)\end{array}$ & $\begin{array}{l}3.57 \pm(0.83) \\
4.01 \pm(0.65)\end{array}$ & $\begin{array}{l}0.53 \\
0.17\end{array}$ & 0.58 \\
\hline $\begin{array}{l}\text { PPT right deltoid } \\
\left(\mathrm{kg} / \mathrm{cm}^{2}\right)\end{array}$ & $\begin{array}{l}\text { Manipulation } \\
\text { Control }\end{array}$ & $\begin{array}{l}3.71 \pm(0.71) \\
3.92 \pm(0.69)\end{array}$ & $\begin{array}{l}3.80 \pm(0.72) \\
3.89 \pm(0.75)\end{array}$ & $\begin{array}{l}3.80 \pm(0.73) \\
3.93 \pm(0.83)\end{array}$ & $\begin{array}{l}0.41 \\
0.19\end{array}$ & 0.38 \\
\hline
\end{tabular}

ASLR, active straight leg raising; VAS, visual analog scale; PPT, pressure pain threshold; PSIS, post superior iliac spine; SIJ sacroiliac joint.

control group at pretest, immediately and 24 hours after the test (Tab. III).

The mean change of the range of hip internal and external rotations before, immediately after and 24 hours after the intervention than sham position, display that there was significant changes $(p<0.05)$, and the maximum increase occurred immediately after intervention.

\section{VAS and active SLR}

The mean change of the level of VAS before, immediately after and 24 hours after the manipulation dimin- ishes significantly $(p<0.05)$, and this decline continued up to 24 hours after the intervention $(p<0.05)$, but there hasn't seen any significant deference in the control group at pretest, immediately and 24 hours after the test (Tab. III). This means that the pain felt by the patients was reduced in treatment group.

The mean score of the ASLR before, immediately after and 24 hours after the manipulation represented that there was significant diminish immediately after the manipulation $(p<0.05)$, and this decline continued up to 24 hours $(p<0.05)$ but there hasn't seen any significant deference in the control group at pretest (Tab. III). 


\section{Pressure pain threshold (PPT)}

The mean change of the outcomes from PPT for the five points, containing right PSIS, right SIJ, left PSIS, left SIJ and right Deltoid, demonstrate that there was no significant variations in both groups at immediately after and 24 hours after the manipulation $(p>0.05)$ (Tab. III).

\section{Discussion}

We measured the range of the flexion and extension of the lumbar spine, the range of internal and external rotations of the hip, VAS, ASLR and PPT at the five points before, immediately after and 24 hours after manipulation in patients with ant innominate or post Innominate dysfunctions for the first time in this study. According to results of this study, manipulation had assisted to relieve the level of pain (VAS) and reduced the average score of active SLR and this efficacy remained up to 24 hours too. This intervention also increased immediately and suddenly the ROM of the internal and external rotations of the hip and the flexion and extension of the lumbar spine but these ROM decreased after 24 hours. This means that the increase in the range of motion after the manipulation is abrupt and temporary, and after 24 hours we have reduced the range of motion, but this is not so much that the range of motion is less than the amount before intervention.

At PPT at the five points we didn't see any significant difference before, immediately after and 24 hours after manipulation in patients; this means that the manipulation did not change notably in PPT.

According to results of this study, manipulation had helped to relieve the level of pain. Based on the hypothesis of gate control theory, Lederman argued that following the manipulation thick afferent fibers of $A \beta$ that induced by mechanical receptors of the facet joints capsule, muscle spindles and skin caused the closure of the pain gate and prevented the central transmission of pain messages.

Bialosky et al. claimed that improvement in VAS could be neurophysiological mechanisms like gate control theory and supraspinal mechanisms ${ }^{19}$.

Also Vernon et al. said that the manipulation of the spine causes release of endorphins, which, by reducing the efficacy of substance of $P$ in the posterior horn of the spinal cord, suppresses pain messages to the centers of the nervous system $(\mathrm{CNS})^{20}$.

The results of this study showed that manipulation had short term effect to increase ROM of lumbar flexion and extension and internal and external rotation of hip.

Increasing the range of joints can be due to reduced muscle tone. Shearar et al. and Maigne et al. have claimed that manipulation reduces hypertonicity by reducing the activity of the motor of the neurons and subsequently reduces pain and muscle spasm up to 15 minutes $^{21,22}$.
Denslow et al. and Lehman et al. were expressed gamma bias hypothesis to increase ROM after manipulation. They claimed that manipulation increases the mobility of target joints by creating a series of impulses that facilitate the gamma motor neuron ${ }^{23.24}$.

A possible physiologic mechanism for our finding is that manipulation may produce post inhibition that due to stimulation of inhibitory interneurons after stretching of the facet joints capsule and decreasing the activity of a motor neurons, paraspinal muscles inhibited 20 .

According to research of Gatterman and Cibulka et al. the mechanical effects of manipulation include realignment the joint and correcting dysfunctional joint motion which can be a reason for an individual's ability to active SLR ${ }^{25}$.

Our findings showed non significant differences in PPT after manipulation. It seems that studies that have found significant differences in PPT after manipulation have done this technique in the upper regions of the spine and mechanoreceptor and nociceptor density in the lower region of the spine (lumbar and sacroiliac joints) is lower than in upper region of the spine ${ }^{19}$.

What distinguishes this article from other articles applying manipulation with consideration of the kind of dysfunction (ant innominate or post Innominate), and we derived that this kind of intervention may be more efficient in curing patients' symptoms.

\section{Conclusions}

The outcomes of this research could support document of the advantages of manipulation. We saw that manipulation could augment the range of lumbar flexion and extension as well as augment the range of internal and external rotations of the hip significantly. In addition, 24 hours after the intervention went on decreasing but the amount of reduction is not less than that before intervention. Therefore, it can be said that increasing the range of motion after manipulation is short-term.

As explained earlier, manipulation could cause decline of pain and hypoalgesia, and in this research, we derived that the use of manipulation causes a decline in the level of pain (VAS). But we didn't see any significant difference in PPT after use of manipulation.

In this study, we concluded that the capability of ASLR increased after manipulation, and therefore derived that manipulation was a treatment that could be an effective to treat sacroiliac dysfunctions.

\section{Suggestions}

There was low number of participants and usage of one gender can be was as limitations of this research. Therefore if this research is repeated with a big number of participants with both genders would be better and is more suitable that future studies evaluate the effects of manipulation on patients with other dysfunctions of SIJ with other techniques. fol- 
low-up of this study is short (24 hours after treatment); it is suggested that future studies consider longer follow-up after intervention.

\section{Acknowledgment}

The Authors would like to appreciate the entire individual who took part, in this research. This study is a part of a PhD thesis and was supported by a grant (\#32486) from Tehran University of Medical Sciences. The authors would like to appreciate the assistance of the faculty and the staff of the TUMS, School of Rehabilitation

\section{Conflict of interest}

The Authors have no personal or financial relationships with other people or organization that could present potential conflict of interest in their works.

\section{References}

1. Sanjeeva Gupta M, Haroon Hameed M, Sudhir Diwan M. A systematic evaluation of prevalence and diagnostic accuracy of sacroiliac joint interventions. Pain physician. 2012;15:E305-E44.

2. Vleeming A, Schuenke M, Masi A, Carreiro J, Danneels L, Willard F. The sacroiliac joint: an overview of its anatomy, function and potential clinical implications. Journal of anatomy. 2012;221(6):537-567.

3. Al-subahi M, Alayat M, Alshehri MA, Helal O, Alhasan $\mathrm{H}$, Alalawi A, Takrouni A, Alfaqeh A. The effectiveness of physiotherapy interventions for sacroiliac joint dysfunction: a systematic review. Journal of physical therapy science. 2017;29(9): 1689-1694.

4. Marshall P, Murphy B. The effect of sacroiliac joint manipulation on feed-forward activation times of the deep abdominal musculature. Journal of manipulative and physiological therapeutics. 2006;29(3):196-202.

5. DeStefano LA. Greenman's principles of manual medicine: Lippincott Williams \& Wilkins. 2011.

6. Carlesso LC, Macdermid JC, Santaguida PL, et al. Beliefs and practice patterns in spinal manipulation and spinal motion palpation reported by Canadian manipulative physiotherapists. Physiotherapy Canada. 2013;65(2):167-175.

7. Cook C. Immediate effects from manual therapy: much ado about nothing? The Journal of manual \& manipulative therapy. 2011;19(1):3.

8. Padulo J, Oliva F, Frizziero A, Maffulli N. Muscles, Ligaments and Tendons Journal - Basic principles and recommendations in clinical and field science research: 2016 update. MLTJ. 2016;6(1):1-5.
9. Vleeming A, Albert HB, Östgaard HC, Sturesson B, Stuge B. European guidelines for the diagnosis and treatment of pelvic girdle pain. European Spine Journal. 2008;17(6):794-819.

10. Robinson HS, Brox JI, Robinson R, Bjelland E, Solem S, Telje $\mathrm{T}$. The reliability of selected motion-and pain provocation tests for the sacroiliac joint. Manual therapy. 2007;12(1):72-79.

11. Szadek KM, van der Wurff $P$, van Tulder MW, Zuurmond WW, Perez RS. Diagnostic validity of criteria for sacroiliac joint pain: a systematic review. The Journal of pain. 2009;10 (4):354-368.

12. Varangaonkar VC, Ganesan S, Kumar KV. The relationship between Lumbar range of motion with hamstring flexibility among 6-12 years children from South India: A cross-sectional study. International Journal of Health \& Allied Sciences. 2015;4(1):23.

13. Fitzgerald GK, Wynveen KJ, Rheault W, Rothschild B. Objective assessment with establishment of normal values for lumbar spinal range of motion. Physical therapy. 1983;63 (11):1776-1781.

14. Kendall FP, McCreary EK, Kendall HO. Muscles, Testing and Function: Testing and Function. 4 ed: Lippincott Williams and Wilkins. 1983.

15. Von Korff M, Jensen MP, Karoly P. Assessing global pain severity by self-report in clinical and health services research. Spine. 2000;25(24):3140-3151.

16. O'sullivan PB, Beales DJ, Beetham JA, et al. Altered motor control strategies in subjects with sacroiliac joint pain during the active straight-leg-raise test. Spine. 2002;27(1):E1-E8.

17. Ylinen J. Pressure algometry. Australian Journal of Physiotherapy. 2007;53(3):207.

18. Reichert B, Stelzenmueller W. Palpation techniques: surface anatomy for physical therapists: TPS. 2015.

19. Bialosky JE, Bishop MD, Price DD, Robinson ME, George SZ. The mechanisms of manual therapy in the treatment of musculoskeletal pain: a comprehensive model. Manual therapy. 2009;14(5):531-538.

20. Vernon H, Dhami M, Howley TP, Annett R. Spinal manipulation and beta-endorphin: a controlled study of the effect of a spinal manipulation on plasma beta-endorphin levels in normal males. Journal of manipulative and physiological therapeutics. 1986;9(2):115-123.

21. Maigne J-Y, Vautravers $P$. Mechanism of action of spinal manipulative therapy. Joint bone spine. 2003;70(5):336-341.

22. Shearar KA, Colloca CJ, White HL. A randomized clinical trial of manual versus mechanical force manipulation in the treatment of sacroiliac joint syndrome. Journal of manipulative and physiological therapeutics. 2005;28(7):493-501.

23. Denslow J, Korr IM, Krems A. Quantitative studies of chronic facilitation in human motoneuron pools. American Journal of Physiology-Legacy Content. 1947;150(2):229-238.

24. Lehman GJ, Vernon H, McGill SM. Effects of a mechanical pain stimulus on erector spinae activity before and after a spinal manipulation in patients with back pain: a preliminary investigation. Journal of Manipulative and Physiological Therapeutics. 2001;24(6):402-406

25. Gatterman MI. Foundations of chiropractic: subluxation. 1 ed: Elsevier Health Sciences. 2005. 